\title{
PENGARUH TEMPERATUR PEMBAKARAN DAN PENAMBAHAN ABU TERHADAP KUALITAS BATU BATA
}

\author{
Oleh:
}

Miftakhul Huda ${ }^{1}$, Erna Hastuti

\begin{abstract}
ABSTRAK : Tanah yang berasal dari desa Pagedangan kecamatan Turen banyak mengandung kaolinite $\left(\mathrm{AL}_{2} \mathrm{Si}_{2} \mathrm{O}_{5}\right)$ dan anothite, sodian, disordered $(\mathrm{Ca}, \mathrm{Na}, \mathrm{Si}, \mathrm{A})$. Kaolinite terbentuk dari perubahan hidrotermal dari mineral-mineral aluminosilikat. Batuan granit merupakan sumber terbesar penghasil kaolinite yang bersifat tidak dapat mengabsorsi air dan tidak mengembang pada saat kontak dengan air. Sehingga lempung desa Pagedangan kecamatan Turen berpotensi dijadikan bahan baku pembuatan keramik bermutu tinggi. Pada penelitian ini dibuat batu bata dengan variasi komposisi tanah liat dan abu dengan perbandingan 1:0, 1: 1/2, 1:1, 1:3 dan dipanaskan pada temperatur sintering $950^{\circ} \mathrm{C}, 1000^{\circ} \mathrm{C}$ dan $1020^{\circ} \mathrm{C}$. Untuk mengetahui kualitas batu bata dilakukan pengujian karakteristik (Uji tekan, porositas, densitas, dan susut bakar) . Hasil karakteristik didapatkan kualitas batu bata yang memenuhi standart SNI yaitu pada variasi 1: 1/2 yang dipanaskan pada temperatur $1020^{\circ} \mathrm{C}$ dengan hasil uji tekan sebesar $11 \mathrm{kN}$ atau $30.5 \mathrm{~kg} / \mathrm{cm}^{2}$, nilai densitas $1,188.10^{4} \mathrm{~kg} / \mathrm{cm}^{3}$, porositas $11.2 \%$, dan nilai susut bakar $0.52 \%$. Batu bata yang berkualitas baik menggunakan variasi 1: $1 / 2$ dan dipanaskan pada temperatur $1000^{\circ} \mathrm{C}-1020^{\circ} \mathrm{C}$.
\end{abstract}

Kata Kunci: Batu Bata, Sintering, Uji Tekan

\section{PENDAHULUAN}

Tanah merupakan salah satu faktor yang terpenting bagi kehidupan manusia. Tak dapat disangkal dan tidak akan ada yang menyangkal bahwa demikianlah halnya, manusia hidup diatas tanah, mencukupi segala kebutuhan hidupnya dengan segala produk yang bahan-bahannya hampir seluruhnya tersedia didalam tanah. Allah S.W.T telah mengingatkan kepada kita bahwa banyak sekali kandungan-kandungan alamiah yang terdapat pada tanah, seperti yang diterangkan dalam Al-Qur'an surat Al A'raaf 58. Desa Pagedangan Kecamatan Turen adalah salah satu daerah penghasil batu bata di Kabupaten Malang.

Komposisi tanah yang berasal dari kecamatan turen mengandung kaolinite $\left(\mathrm{Al}_{2} \mathrm{Si}_{2} \mathrm{O}_{5}(\mathrm{OH})_{4}\right)$ dan $(\mathrm{Ca}, \mathrm{Na})(\mathrm{Si}, \mathrm{Al})_{4} \mathrm{O}_{8}$ (anothite, sodian, disordered). Kaolinite terbentuk dari perubahan hidrotermal dari mineral-mineral aluminosilikat. Batuan granit merupakan sumber terbesar penghasil kaolinite. Sifat dari kaolinite adalah tidak dapat mengabsorsi air, kaolinite tidak dapat mengembang pada saat kontak dengan air. Sehingga lempung Pagedangan berpotensi dijadikan bahan baku pembuatan keramik bermutu tinggi atau berkualitas baik.

Penelitian ini bertujuan untuk mengetahui karakteristik (uji tekan, penyerapan air, susut bakar, densitas) batu bata yang berkualitas baik dan mengetahui suhu pembakaran yang dibutuhkan untuk menghasilkan batu bata yang berkualitas baik.

1,2 Jurusan Fisika Fakultas Sains dan Teknologi UIN Maliki Malang 


\section{KAJIAN TEORI}

Tanah merupakan bahan baku dari poses pembuatan batu bata, dimana kegunaannya sangat menguntungkan bagi manusia karena bahan baku dari batu bata yang mudah didapatkan. Dari segi bentuk batu bata mudah ditata atau dipasang untuk lantai, maupun dinding. Tanah memiliki beberapa sifat-sifat yang khas yaitu bila dalam keadaan basah mempunyai sifat plastis tetapi bila dalam keadaan kering menjadi keras, sedangkan bila dibakar menjadi kuat dan padat. Pada umumnya, masyarakat memanfaatkan tanah atau lempung ini sebagai bahan baku proses pembuatan batu bata dan gerabah.

Abu sisa pembakaran mengandung senyawa silica-alumina aktif yang dapat bereaksi dengan kalsium hidroksida pada suhu kamar dan adanya air pada kadar tertentu dapat membentuk senyawa stabil yang mempunyai sifat mengikat. Selain air dipakai dalam proses reaksi pengikatan material yang digunakan untuk pembuatan batu bata, juga dapat mempermudah pencetakan batu bata.

Keramik adalah senyawa yang mengandung unsur logam dan non-logam. Banyak sekali contoh material keramik, mulai dari semen pada beton (bahkan batuan), gelas, isolator listrik, dan magnet permanen. Pengertian proses keramik adalah rangkaian perlakuan-perlakuan secara sistematik sehingga menghasilkan perubahan-perubahan dalam aspek fisika dan kimia (selanjutnya disebut karakteristik dari sistem). Proses keramik, secara umum dapatlah dibagi menjadi empat tahapan: Pemilihan bahan baku; Kalsinasi; Forming (pencetakan); Sintering (pemanasan) (Suasmoro, 2005).

Batu bata adalah salah satu unsur bangunan dalam pembuatan konstruksi bangunan yang terbuat dari tanah liat ditambah air dengan atau tanpa bahan campuran lain melalui beberapa tahap pengerjaan, seperti menggali, mengolah, mencetak, mengeringkan, membakar pada temperatur tinggi hingga matang dan berubah warna, serta akan mengeras seperti batu jika didinginkan hingga tidak dapat hancur lagi bila direndam dalam air (Ramli, 2007).

Proses pembuatan batu bata melalui beberapa tahapan, meliputi penggalian bahan mentah, pengolahan bahan, pembentukan, pengeringan, pembakaran, pendinginan, dan pemilihan (seleksi). Adapun tahap-tahap pembuatan batu bata, yaitu sebagai berikut; (Suwardono, 2002)

\section{Penggalian Bahan Mentah}

Penggalian bahan mentah batu bata merah sebaiknya dicarikan tanah yang tidak terlalu plastis, melainkan tanah yang mengandung sedikit pasir untuk menghindari penyusutan. Penggalian dilakukan pada tanah lapisan paling atas kira-kira setebal 40-50 $\mathrm{cm}$, sebelumnya tanah dibersihkan dari akar pohon, plastik, daun, dan sebagainya agar tidak ikut terbawa. Kemudian menggali sampai ke bawah sedalam 1,5-2,5 meter atau tergantung kondisi tanah. Tanah yang sudah digali dikumpulkan dan disimpan pada tempat yang terlindungi. Semakin lama tanah liat disimpan, maka akan semakin baik 
karena menjadi lapuk. Tahap tersebut dimaksudkan untuk membusukkan organisme yang ada dalam tanah liat.

\section{Pengolahan Bahan Mentah}

Tanah liat sebelum dibuat batu bata merah harus dicampur secara merata yang disebut dengan pekerjaan pelumatan dengan menambahkan sedikit air. Air yang digunakan dalam proses pembuatan batu bata harus air bersih, air harus tidak sadah tidak mengandung garam yang larut di dalam air, seperti garam dapur, air yang digunakan kirakira 20\% dari bahan-bahan yang lainnya, pelumatan bisa dilakukan dengan kaki atau diaduk dengan tangan. Bahan campuran yang ditambahkan pada saat pengolahan harus benar-benar menyatu dengan tanah liat secara merata. Bahan mentah yang sudah jadi ini sebelum dibentuk dengan cetakan, terlebih dahulu dibiarkan selama 2 sampai 3 hari dengan tujuan memberi kesempatan partikel-partikel tanah liat untuk menyerap air agar menjadi lebih stabil, sehingga apabila dibentuk akan terjadi penyusutan yang merata.

\section{Pembentukan Batu Bata}

Bahan mentah yang telah dibiarkan 2-3 hari dan sudah mempunyai sifat plastisitas sesuai rencana, kemudian dibentuk dengan alat cetak yang terbuat dari kayu atau kaca sesuai ukuran standart SNI S-04-1989-F atau SII-0021-78. Supaya tanah liat tidak menempel pada cetakan, maka cetakan kayu atau kaca tersebut dibasahi air terlebih dahulu. Lantai dasar pencetakan batu bata merah permukaannya harus rata dan ditaburi abu. Langkah awal pencetakan batu bata yaitu letakkan cetakan pada lantai dasar pencetakan, kemudian tanah liat yang telah siap ditaruh pada bingkai cetakan dengan tangan sambil ditekan-tekan sampai tanah liat memenuhi segala sudut ruangan pada bingkai cetakan. Selanjutnya cetakan diangkat dan batu bata mentah hasil dari cetakan dibiarkan begitu saja agar terkena sinar matahari. Batu bata mentah tersebut kemudian dikumpulkan pada tempat yang terlindung untuk diangin-anginkan.

\section{Pengeringan Batu Bata Merah}

Proses pengeringan batu bata akan lebih baik bila berlangsung secara bertahap agar panas dari sinar matahari tidak jatuh secara langsung, maka perlu dipasang penutup plastik. Apabila proses pengeringan terlalu cepat dalam artian panas sinar matahari terlalu menyengat akan mengakibatkan retakan-retakan pada batu bata nantinya. Batu bata yang sudah berumur satu hari dari masa pencetakan kemudian dibalik. Setelah cukup kering, batu bata tersebut ditumpuk menyilang satu sama lain agar terkena angin. Proses pengeringan batu bata memerlukan waktu dua hari jika kondisi cuacanya baik. Sedangkan pada kondisi udara lembab, maka proses pengeringan batu bata sekurang-kurangnya satu minggu.

\section{Pembakaran Batu Bata}

Pembakaran yang dilakukan tidak hanya bertujuan untuk mencapai suhu yang dinginkan, melainkan juga memperhatikan kecepatan pembakaran untuk mencapai suhu tersebut serta kecepatan untuk mencapai pendinginan. Selama proses pembakaran terjadi perubahan fisika dan kimia serta mineralogy dari tanah liat tersebut. Proses pembakaran 
batu bata harus berjalan seimbang dengan kenaikan suhu dan kecepatan suhu, ada beberapa tahapan yang harus diperhatikan, yaitu: (Suwardono, 2002)

a. Tahap pertama adalah penguapan (pengeringan), yaitu pengeluaran air pembentuk, terjadi hingga temperatur kira-kira $120^{\circ} \mathrm{C}$.

b. Tahap oksidasi, terjadi pembakaran sisa-sisa tumbuhan (karbon) yang terdapat di dalam tanah liat. Proses ini berlangsung pada temperatur $650^{\circ} \mathrm{C}-800^{\circ} \mathrm{C}$.

c. Tahap pembakaran penuh. Batu bata dibakar hingga matang dan terjadi proses sintering hingga menjadi bata padat. Temperatur matang bervariasi antara $920^{\circ} \mathrm{C}$ $1020^{\circ} \mathrm{C}$ tergantung pada sifat tanah liat yang dipakai.

d. Tahap penahanan. Pada tahap ini terjadi penahanan temperatur selama 1-2 jam. Pada tahap 1, 2 dan 3 kenaikan temperatur harus perlahan-lahan, agar tidak terjadi kerugian pada batanya. Antara lain: pecah-pecah, noda hitam pada bata, pengembangan, dan lain-lain.

Salah satu cara yang umum digunakan dalam pengujian mekanik tegangan regangan adalah bentuk kerja bahan karena pengaruh tegangan. Suatu spesimen dideformasi, sampai patah dengan beban tegangan bertambah secara perlahan-lahan (continue) yang dikenakan pada salah satu sumbunya atau dalam arah tunggal sepanjang sumbu panjang dari spesimen.

Mesin pengujian tegangan di rancang untuk memperpanjang spesimen pada laju konstan secara continue mengukur beban yang dipakai dan menghasilkan perpanjangan. Tipe pengujian tegangan regangan dilakukan dalam beberapa menit untuk mengetahui bentuk kerja bahan sampai mengalami kerusakan, spesimen mengalami deformasi dan sampai patah (Arifin, 2001).

Susut Bakar adalah perubahan dimensi atau volume bahan yang telah dibakar. Salah satu parameter yang menunjukkan terjadinya proses sintering adalah penyusutan akibat adanya perubahan mikrostruktur (butir atau batas butir).

Porositas pada suatu material dinyatakan dalam persen (\%) rongga fraksi volume dari suatu rongga yang ada dalam material tersebut. Besarnya porositas pada suatu material bervariasi mulai dari $0 \%$ sampai dengan $90 \%$ tergantung dari jenis dan aplikasi material tersebut. Semakin banyak porositas yang terdapat pada benda uji maka semakin rendah kekuatannya, begitu pula sebaliknya.

\section{METODE PENELITIAN}

Alat dan bahan yang digunakan pada penelitian ini terdiri Timbangan Heles model Ek 8250. Oven/Furnaces Fisher Scientific model 655F. Compression Machine merk KAN. Jangka sorong Vernier Caliper $200 \times 0.02 \mathrm{~mm}$. Alat cetak Batu Bata Ukuran 6,5 X 9 X 19 $\mathrm{cm}$. Pengaduk. Cawan. Tanah Liat atau Tanah Lempung. Abu Kayu. Air secukupnya. 
Pengujian Karakteristik ini meliputi: (Uji Kuat Tekan, Susut Bakar, Penyerapan Air, Densitas). Proses pembuatan batu bata dengan penambahan abu dengan variasi 1:0, 1: 1/2, 1:1, 1:3. Kemudian batu bata di panaskan dibawah terik matahari kurang lebih 3-4 hari, Batu bata yang sudah jadi dibakar pada suhu $120^{\circ} \mathrm{C}$ untuk menghilangkan sisa-sisa air. Kemudian dilanjutkan pembakaran pada suhu $800^{\circ} \mathrm{C}$ yaitu untuk menghilangkan karbon yang ada pada abu serta menghilangkan kandungan-kandungan tanah yang bisa menyebabkan batu bata mudah patah dan retak-retak. Kemudian batu bata dibakar pada suhu $950^{\circ} \mathrm{C}, 1000^{\circ} \mathrm{C}, 1020^{\circ} \mathrm{C}$ masing-masing 3 sampel dan 2 batu bata pada setiap suhu pembakaran. Batu bata setelah dibakar kemudian di uji tekan dengan cara batu bata di potong membentuk seperti kubus kemudian di masukkan dalam alat uji tekan(Compression Machine). UJi lainya yaitu porositas, densitas, susut bakar.

\section{HASIL DAN PEMBAHASAN}

\section{Nilai Densitas dan Porositas Batu Bata}

Dari data pengukuran volume dan massa batu bata sebelum dan sesudah dibakar atau disintering, di dapatkan nilai densitas batu bata. Yang diperoleh dari persamaan:

$$
\rho=\frac{m}{v}
$$

\section{Dimana:}

m: massa batu bata $(\mathrm{kg})$

v: Volume batu bata $\left(\mathrm{m}^{3}\right)$.

Hasil perhitungan dari nilai densitas rata-rata ditunjukkan pada pada tabel 1 di bawah ini:

Tabel 1 Nilai densitas rata-rata sebelum dan sesudah dibakar

\begin{tabular}{|c|c|c|c|c|}
\hline No & $\begin{array}{l}\text { Komposisi } \\
\text { Abu : Tanah }\end{array}$ & $\begin{array}{l}\text { Kode } \\
\text { Sampel }\end{array}$ & $\begin{array}{l}\quad 0 \\
\text { sebelum sintering } \\
\left(\mathrm{kg} / \mathrm{m}^{3}\right)\end{array}$ & $\begin{array}{l}1 \\
\text { sesudah sintering } \\
\left(\mathrm{kg} / \mathrm{m}^{3}\right)\end{array}$ \\
\hline \multirow{4}{*}{1.} & \multirow{3}{*}{$1: 0$} & $\bar{A}$ & 1,386 & 1,229 \\
\hline & & B & 1,358 & 1,192 \\
\hline & & $\mathrm{C}$ & 1,328 & 1,182 \\
\hline & & $\mathrm{D}$ & 1,407 & 1,219 \\
\hline
\end{tabular}




\begin{tabular}{|l|c|c|c|c|}
\hline 2. & $1: 1 / 2$ & $\mathrm{E}$ & 1,413 & 1,222 \\
\cline { 3 - 5 } & & $\mathrm{F}$ & 1,391 & 1,188 \\
\hline \multirow{3}{*}{3.} & \multirow{3}{*}{$1: 1$} & $\mathrm{G}$ & 1,307 & 1,142 \\
\cline { 3 - 5 } & & $\mathrm{H}$ & 1,147 & 1,165 \\
\cline { 3 - 5 } & & $\mathrm{I}$ & 1,260 & 1,132 \\
\hline \multirow{3}{*}{4.} & \multirow{3}{*}{$1: 3$} & $\mathrm{~J}$ & 1,062 & 0.619 \\
\cline { 3 - 5 } & & $\mathrm{K}$ & 1,112 & 0,777 \\
\cline { 3 - 5 } & & $\mathrm{L}$ & 1,109 & 1,042 \\
\hline
\end{tabular}

Dari hasil perhitungan nilai densitas rata-rata batu bata yang belum dan sudah dibakar di dapatkan grafik fungsi antara komposisi abu dengan nilai densitas. Seperti yang ditunjukkan pada grafik di bawah ini:

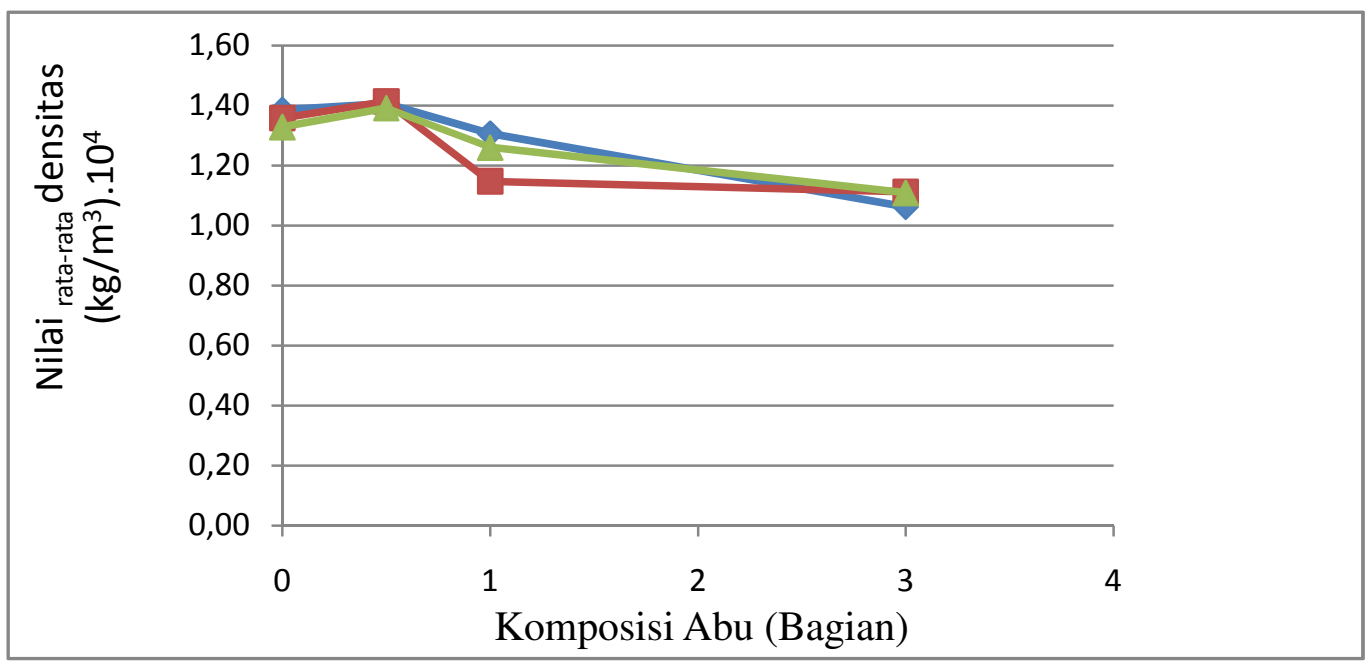

Grafik 1. Variasi sampel terhadap Nilai densitas rata-rata sebelum dibakar. 


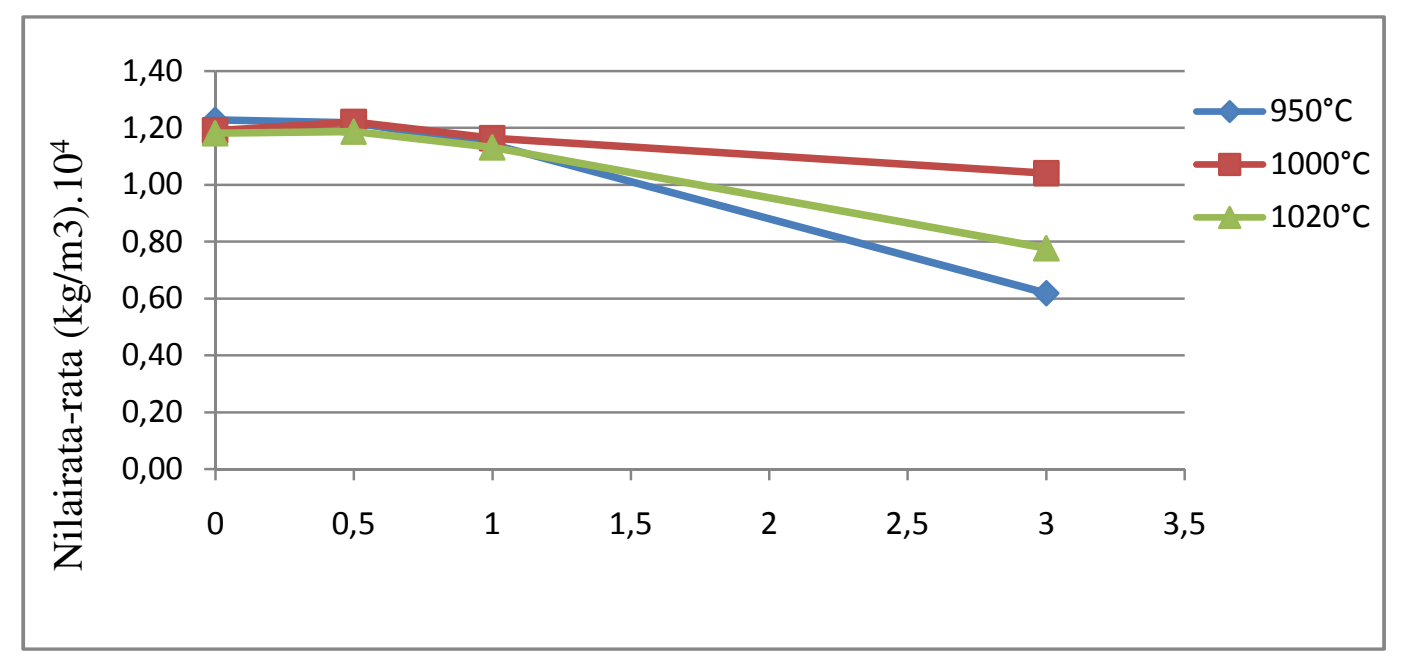

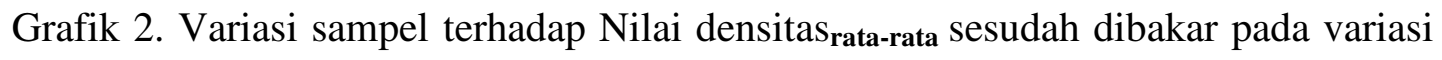
temperatur sintering.

Porositas merupakan salah satu cara untuk mengetahui kualitas batu bata. Data porositas didapatkan dari nilai batu bata basah (direndam dalam air) dan nilai batu bata kering.

Dari perhitungan data nilai porositas diatas didapatkan grafik fungsi antara nilai porositas terhadap temperatur sintering.

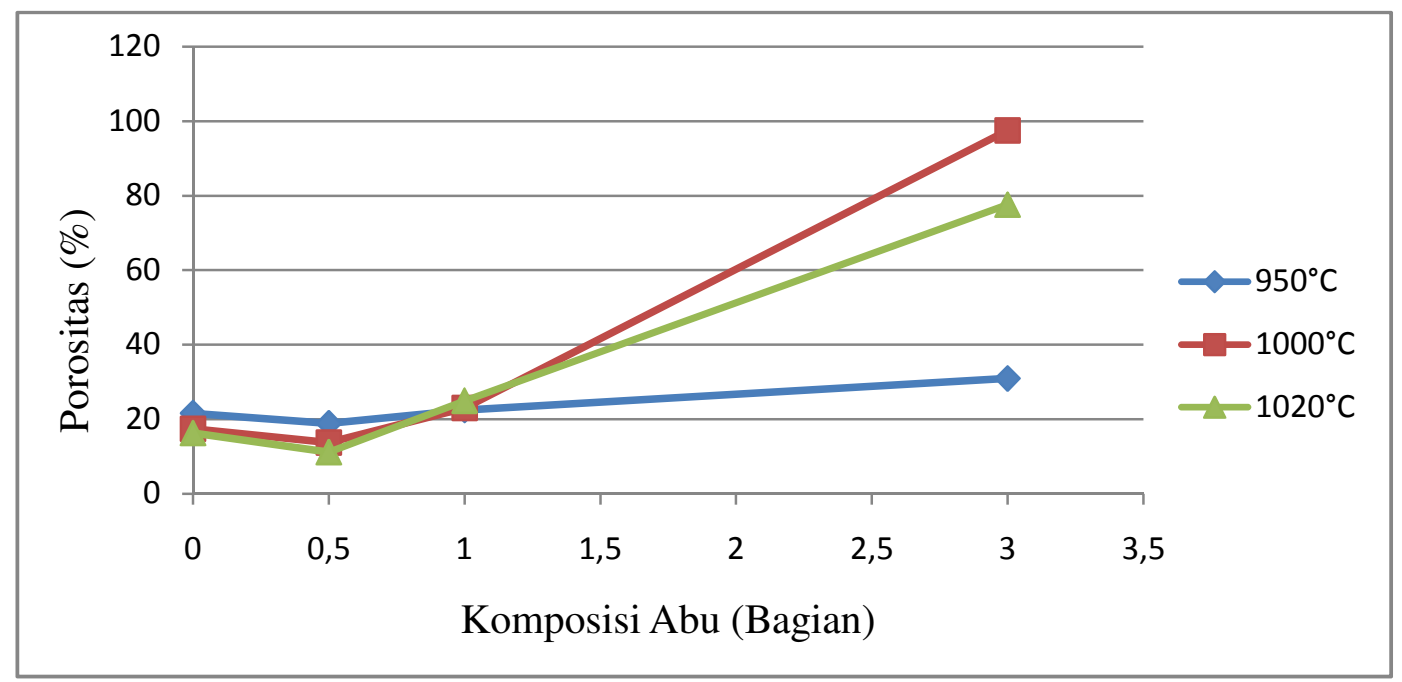

Grafik 3. Hubungan antara komposisi abu terhadap nilai porositas pada variasi temperatur sintering.

Densitas dari setiap sampel untuk masing-masing bentuk dan masing-masing ukuran ditentukan melalui perbandingan massa dan volume. Hasil untuk pengukuran nilai densitas yang didapatkan melalui penelitian sebagaimana yang tertera pada grafik 1 bisa kita perhatikan bahwa nilai rata-rata dari densitas batu bata sebelum dibakar menunjukkan nilai yang hampir sama disetiap sampel yang digunakan. Hal ini bisa terjadi karena batu bata belum mendapatkan pengaruh dari suhu pembakaran, sehingga bentuk dan massa batu bata masih dalam keadaan tidak berubah. Tapi pada sampel variasi penambahan abu 
$1: 3$ nilai densitasnya mengalami penurunan, hal ini disebabkan oleh banyaknya jumlah abu yang digunakan pada saat proses pembuatan batu bata sehingga batu bata memiliki nilai densitas yang lebih kecil.

Batu bata yang sudah disentering nilai densitas rata-rata mengalami perubahan pada setiap sampel. Pada variasi temperatur sintering, masing-masing sampel tidak mengalami perubahan nilai densitas yang sangat signifikan. Pada grafik 2 menunjukkan bahwa batu bata dengan penambahan abu, nilai densitas menjadi semakin besar pada komposisi variasi $1: 1 / 2$. Penambahan abu pada komposisi $1: 1$ dan $1: 3$ nilai densitasnya semakin menurun. Hal ini disebabkan karena silica-alumina yang ada pada abu ketika dipnaskan pada suhu tinggi banyak yang menguap sehingga didalam batu bata menjadi lebih banyak ronggarongga. Semakin banyak abu yang ditambahkan dalam proses pembuatan batu bata, nilai densitasnya semakin menurun. Selain itu kerapatan pada saat proses pembuatan batu bata juga mempengaruhi kualitas batu bata, misalnya pengadukan atau percampuran komposisi variasi dan pada saat pencetakan, penekanan pada saat mencetak batu bata.

Porositas dan densitas sangat berhubungan, jika nilai densitas tinggi maka nilai porositasnya berkurang. Porositas tinggi mengakibatkan kualitas batu bata menjadi rendah, batu bata ketika digunakan akan menjadi lebih mudah patah. Perhitungan tentang porositas ini ditunjukan pada grafik 3. Data yang diperoleh dari pengukuran nilai porositas pada batu bata yang menggunakan komposisi variasi abu 1 : 0 menunjukkan nilai penyerapan air yang cukup besar. Pada temperatur $950^{\circ} \mathrm{C}, 1000^{\circ} \mathrm{C}$ dan $1020^{\circ} \mathrm{C}$ hasilnya $21.6 \%$, 17.4\% dan 16.3\%. Pada variasi komposisi 1 : 1/2 nilai porositas lebih kecil dibandingkan dengan nilai porositas pada variasi 1 : 0 yaitu $18.9 \%$, pada $13.7 \%$ dan 11.2\%. Pada variasi ini batu bata menjadi lebih keras dan mengalami pemadatan. Pembakaran pada suhu tinggi mengakibatkan rongga-rongga didalam batu bata berkurang sehingga batu bata menjadi lebih kuat. Pada variasi komposisi 1 : 1 nilai porositas mengalami peningkatan. Dilihat dari segi fisiknya batu bata menjadi lebih ringan. Batu bata yang menggunakan variasi $1: 1$ tidak mengalami ikatan yang sempurna antar partikel sehingga rongga-rongga yang ada didalam batu bata sangat banyak, rongga-rongga ini berasal dari abu yang ditambahkan pada saat proses pembuatan batu bata terbakar atau menguap, sehingga batu bata mudah patah. Nilai dari porositas variasi komposisi $1: 1$ yaitu 22,5\%, 23\%, dan 25\%. Pada perbandingan 1:3 menunjukkan kualitas batu bata yang buruk, dari segi fisik batu bata lebih ringan dan rapuh, dari segi warna batu bata yang menggunakan variasi $1: 3$ tidak menunjukkan warna batu bata yaitu berwarna kemerahmerahan melainkan warna abu-abu (batu bata setelah disinari matahari), sehingga nilai porositas batu bata pada variasi $1: 3$ mengalami kenaikan yang cukup tinggi, bahkan nilai porositas tertinggi diantara variasi yang lainnya. Pada variasi $1: 3$ batu bata yang di uji tidak menggunakan batu bata yang masih utuh seperti sampel yang lainya, hal ini dikarenakan batu bata yang menggunakan variasi 1: 3 ketika dikeluarkan dari Furnaces sudah dalam keadaan hancur, sehingga pengukuran porositas menggunakan batu bata yang masih memungkinkan untuk bisa dicari nilai panjang, lebar maupun tingginya. Nilai dari porositas pada variasi $1: 3$ pada temperature yang berbeda masing-masing sebesar $30.9 \%$, $97.5 \%$, dan $77.6 \%$. Untuk pengukuran baik maupun buruknya batu bata dari perhitungan 
porositas ini sangat bergantung pada penambahan abu, suhu pembakaran(sintering), dan juga bahan utama.

\section{Nilai Uji Tekan}

Batu bata yang sudah disintering kemudian di uji tekan. Bahan yang di uji dipotong menjadi $6 \times 6 \mathrm{~cm}^{2}$ kemudian alat dijalankan kita tunggu sampai batu bata hancur atau retak-retak. Hasil pengujian dibuat grafik fungsi antara komposisi tanah : abu dengan kuat tekan. Didapatkan grafik hubungan antara komposisi tanah : abu dengan kuat tekan.

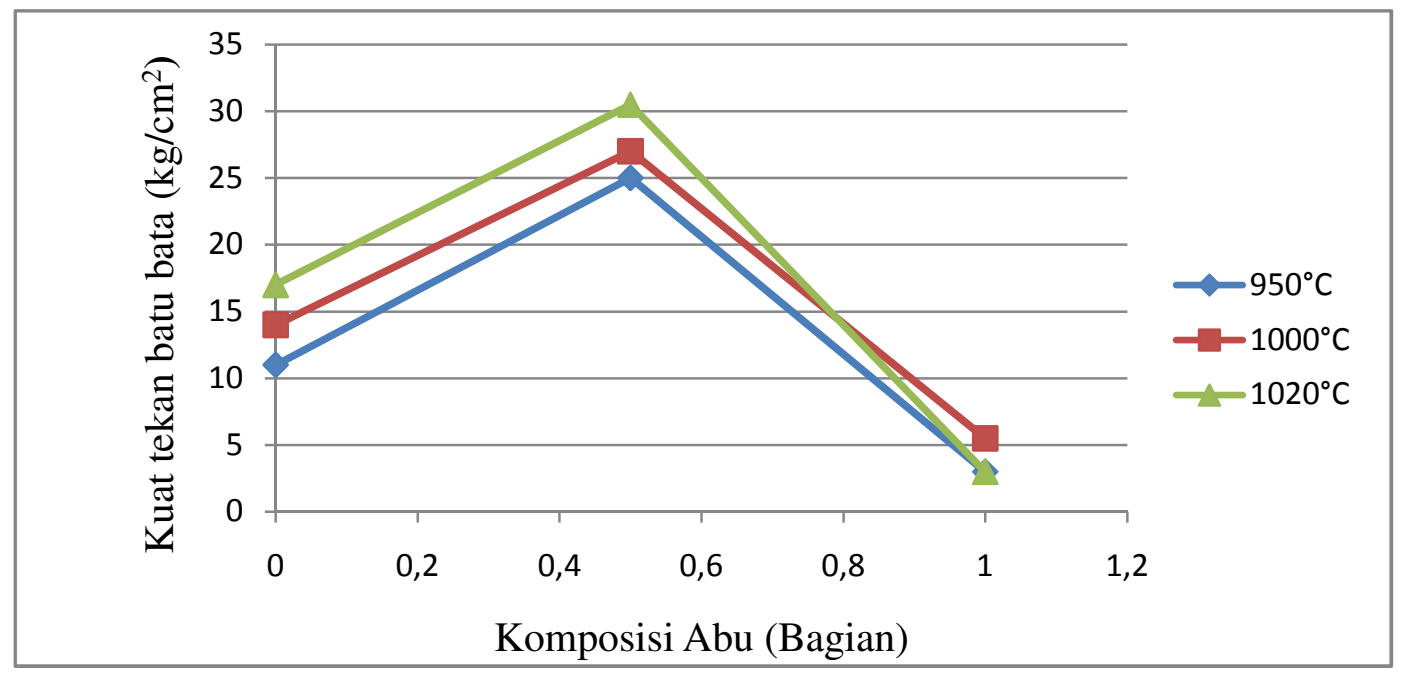

Grafik 4. Hubungan komposisi tanah : abu terhadap nilai uji tekan pada variasi temperatur sintering.

Dari hasil pengukuran uji tekan didapatkan nilai uji tekan yang bervariatif dari berbagai variasi komposisi. Uji tekan dilakukan untuk mengetahui kualitas batu bata. Salah satu cara yang umum digunakan dalam pengujian mekanik tegangan regangan adalah bentuk kerja bahan karena pengaruh tegangan. Kuat tekan suatu material didefenisikan sebagai kemampuan material dalam menahan beban atau gaya mekanis sebagai kemampuan material dalam menahan beban atau gaya mekanis sampai terjadinya kegagalan. Pada grafik 4 menunjukkan nilai variasi pada komposisi variasi 1 : 0 nilai uji tekan berada di bawah nilai standart uji tekan batu bata. Nilai standart sesuai (SNI) batu bata pada kelas 25 nilai kuat rata-rata minimum batu bata sebesar $25 \mathrm{~kg} / \mathrm{cm}^{2}$. Hasil uji tekan pada temperatur $950^{\circ} \mathrm{C}, 1000^{\circ} \mathrm{C}$ dan $1020^{\circ} \mathrm{C}$ diperoleh hasil masing-masing sebesar 11- $14 \mathrm{~kg} / \mathrm{cm}^{2}, 11-14 \mathrm{~kg} / \mathrm{cm}^{2}$ dan $14-17 \mathrm{~kg} / \mathrm{cm}^{2}$. Nilai yang sesuai standart uji tekan batu bata ada pada sampel variasi komposisi $1: 1 / 2$. Hal ini dikarenakan abu sisa pembakaran yang digunakan dalam pencampuran batu bata mengandung senyawa silica-alumina aktif yang dapat bereaksi dengan kalsium hidroksida pada suhu kamar dan adanya air pada kadar tertentu dapat membentuk senyawa stabil yang mempunyai sifat mengikat. Hasil uji tekan pada variasi $1: 1 / 2$ diperoleh nilai $22-25 \mathrm{~kg} / \mathrm{cm}^{2}, 25-27 \mathrm{~kg} / \mathrm{cm}^{2}$ dan $30.5 \mathrm{~kg} / \mathrm{cm}^{2}$. Pada variasi $1: 1$ nilai uji tekan batu bata mengalami penurunan nilai uji tekan ini disebabkan terlalu banyak abu yang digunakan dalam percampuran pembuatan batu bata, sehingga batu bata menjdi lebih rapuh dan berada dibawah dari nilai standart uji tekan batu bata. 
Hasil uji tekan dari variasi $1: 1$ yaitu $3 \mathrm{~kg} / \mathrm{cm}^{2}, 5.5 \mathrm{~kg} / \mathrm{cm}^{2}$, dan $3 \mathrm{~kg} / \mathrm{cm}^{2}$. Pada variasi $1: 3$ batu bata tidak dapat dilakukan uji tekan karena batu bata setelah disintering batu bata menjadi sangat rapuh, sehingga ketika dilakukan uji tekan alat uji tekan tidak bisa membaca nilai kuat dari batu bata tersebut.

\section{Nilai Susut Bakar}

Setelah proses pembakaran suatu benda akan mengalami perubahan panjang. Dalam hal ini lempung akan mengalami penyusutan karena air dalam lempung menguap. Dari data susut bakar rata-rata dapat diperoleh grafik fungsi antara nilai susut bakar $\mathrm{Sb}(\%)$ ratarata dengan Temperatur sintering.

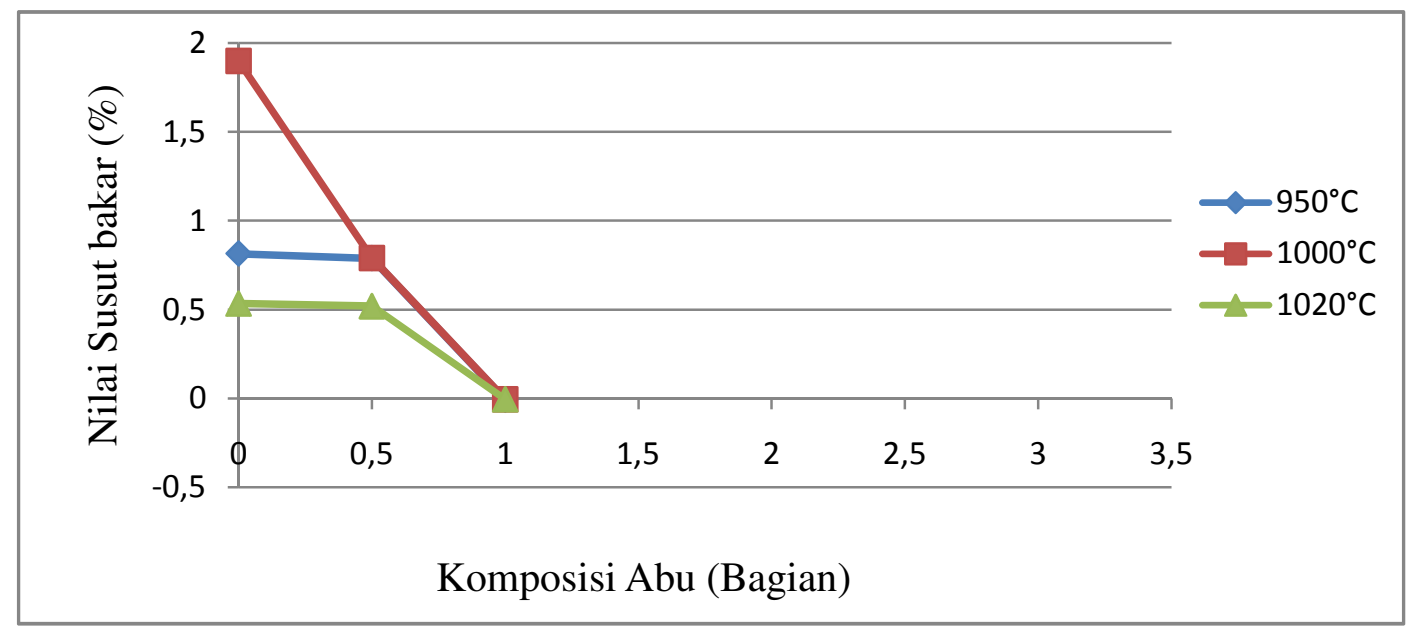

Grafik 5. Hubungan antara komposisi abu dengan nilai rata-rata susut bakar pada variasi temperatur sintering.

Dari hasil penelitian didapatkan nilai seperti pada grafik 5 hubungan antara komposisi abu terhadap nilai susut bakar pada variasi temperatur sintering. Pada variasi komposisi tanah:abu 1 : 0 nilai susut bakar rata-rata menunjukkan nilai yang tidak stabil, sehingga nilainya naik turun. Pada variasi komposisi $1: 1 / 2$ pada suhu yang tetap nilai susut bakar menunjukkan nilai yang stabil. Selanjutnya pada komposisi $1: 1$ nilai susut bakar menunjukkan nilai negatif, ini dikarenakan batu bata ketika dibakar tidak menunjukkan penyusutan melainkan pemuaian batu bata. Tanah liat tidak bisa berubah menjadi bentuk keramik yang keras dan padat karena abu yang mengandung silika yang dicampurkan dalam proses pembuatan batu bata tidak bisa teroksidasi sempurna dengan tanah liat yang berasal dari desa pagedangan kecamatan Turen yang banyak mengandung kaolinite. Pada variasi 1:3 batu bata setelah dibakar rata-rata batu bata hancur maupun retak-retak, sehingga tidak bisa dilakukan pengukuran susut bakar.

\section{KESIMPULAN}

Pengujian karakteristik batu bata yang berkualitas baik dan sesuai dengan standart SNI adalah batu bata yang menggunakan variasi komposisi $1: 1 / 2$. Dengan nilai uji tekan sampel yang disinterring pada temperatur $950^{\circ} \mathrm{C}, 1000^{\circ} \mathrm{C}$ dan $1020^{\circ} \mathrm{C}$ yaitu $22-25$ 
$\mathrm{kg} / \mathrm{cm}^{2}, 25-27 \mathrm{~kg} / \mathrm{cm}^{2}$ dan $30.5 \mathrm{~kg} / \mathrm{cm}^{2}$. Nilai densitas rata-rata sesudah dibakar pada temperatur $950^{\circ} \mathrm{C}, \quad 1000^{\circ} \mathrm{C}$ dan $1020^{\circ} \mathrm{C}$ adalah sebesar $1,219.10^{4} \mathrm{~kg} / \mathrm{cm}^{3}$, $1,222.10^{4} \mathrm{~kg} / \mathrm{cm}^{3}$ dan $1,188.10^{4} \mathrm{~kg} / \mathrm{cm}^{3}$. Nilai porositasnya $18.9 \%, 13.7 \%$ dan $11.2 \%$. Sedangkan nilai susut bakarnya adalah $0.79 \%, 0.79 \%$, dan $0.52 \%$. Pada penelititian ini batu bata yang berkualitas baik yaitu pada komposisi perbandingan tanah : abu (1: 1/2). Nilai uji tekan batu bata termasuk dalam kelas 25 (SNI). Untuk menghasilkan batu bata yang berkualitas baik diperlukan temperatur tinggi dalam proses pembakaran antara $1000^{\circ} \mathrm{C}-1020^{\circ} \mathrm{C}$ karena pada suhu tinggi batu bata mengalami ikatan partikel yang sempurna, partikel-partikel mengalami perubahan bentuk yang saling mengisi pori-pori sehingga batu bata menjadi lebih kuat dan keras.

\section{DAFTAR PUSTAKA}

Aji, Setyo.B dan Anjar. 2009. The Role Of a Coal Gasification Fly Ash as Clay Addive in Building Ceramic. Journal of the European Ceramic Sosiety 26 (2006) 3783-3787.

Hanafiah, Kemas A. 2005. Dasar-dasar Ilmu Tanah. Jakarta: PT Rajagrafindo Persada.

Muhardi, Reni Suryanita, Alsaidi. 2007. Perbaikan Karakteristik Batu Bata Lempung Dengan Penambahan Abu Terbang. Riau: Jurusan Teknik Sipil Fakultas Teknik Universitas Riau.

Nelly, Komang Sundari 2010. Pengaruh Perlakuan Suhu Bakar Pada Massa Bodi Keramik Stone Kode BL 1 Terhadap Parameter Penyusutan dan Peresapan Air. Bali: Skripsi.

P.U. 1991. SNI 15 -2094-1991 tentang Bata Merah Pejal. Jakarta: Pekerjaan Umum.

Ramli \& Djamas, Djusmaini. 2007. Pengaruh Pemberian Material Limbah Serat Alami Terhadap Sifat Fisika Bata Merah, Padang.

Suwardono. 2002. Mengenal Pembuatan Bata,Genteng,Genteng Berglasir, Cetakan Pertama. Bandung: CV. Yrama Widya.

Suasmoro, Dr. 2000. Fisika Keramik. Surabaya. Jurusan Fisika FMIPA ITS.

Subiyanto, Hari Subowo. 2003. Pengaruh Temperatur Sintering terhadap Sifat Mekanik Keramik Insulator Listrik. Surabaya: ITS.

Tamam, Moh. Qodari. 2010. Karakteristik Lempung dari Daerah Pagedangan Kec Turen Kab Malang dan Daerah Getaan Kec Pagelaran Kab Malang. Malang. Jurusan Kimia Fakultas Sains dan Teknologi UIN Maliki Malang. Skripsi.

Van Vlack, Lawrence. H. 2004. Elemen - Elemen Ilmu Dan Rekayasa Material. Jakarta: Erlangga. 